\title{
THE SHIFT AND CONTINUITY OF THE PHILIPPINES' FOREIGN POLICY UNDER RODRIGO DUTERTE ON THE SOUTH CHINA SEA ISSUE
}

\author{
Jennie Joyce Candice ${ }^{1}$, Anak Agung Banyu Perwita ${ }^{2}$ \\ 1Program Studi Ilmu Hubungan Internasional Fakultas Ilmu Sosial dan \\ Ilmu Politik President University, \\ jenniefebrian@gmail.com \\ 2Program Studi Diplomasi Pertahanan Universitas Pertahanan Indonesia, \\ aabanyu.perwita@gmail.com
}

\begin{abstract}
The South China Sea (SCS) has become the largest and the crucial Sea Lanes of Communication (SLOCs) not only for Southeast Asia but also for the world. As one of the claimants of the South China Sea, Philippines were always and will always be trying to protect its national interests in the disputed waterways as part of its national territory. This article discusses about the shift and continuity of the Philippines' foreign policy on the South China Sea issue. It explicates the shift and continuity of Philippines foreign policy under Rodrigo Duterte to the South China Sea. A more focus elaboration will be devoted on how the Philippines implemented its foreign policy to deal with China in the South China Sea dispute.It argues that Duterte foreign policy to this delicate issue is always based on the strategic dynamic of its "two-level game" (domestic and international political stimuli) to its national interests.
\end{abstract}

Keywords: Foreign Policy, National Interests, South China Sea, Sea Lanes of Communications (SLOCs)

\section{Introduction}

As South China Sea region is the important aspect for the Sea Lanes of Communication (SLOC) and also contains a lot of natural resources such as hydrocarbons, there's no doubt that South China Sea becomes the disputed area for the all of the neighborhood states and it has triggered the claimant states are growing their own interests in that region (EIA, 2019). The Philippines' is one of the claimant countries which are having the interests over South China Sea. The national interests of Philippines' consist 
of three aspects; there are political interests, economics interests, and security interests. Obviously, there was a significant change of the Philippine foreign policy from the former president Benigno Aquino III 'balancing policy' to Rodrigo Duterte 'independent foreign policy' in dealing with the South China Sea dispute in order to achieve the Philippines national interests in the SCS. The 'balancing policy' under Aquino III means to balance the Philippines relations with the major powers specifically between the US and China without taking sides (Javad Heydarian, 2011). But during Aquino III administration, he has changed and pursued the foreign policy known as balancing policy or challenging policy in facing China aggressive behavior in the SCS by making a closer defence relations and to conduct the bilateral security cooperation with the US(Castro R. C., 2014).

The shift and continuity of the Philippines foreign policy happened since the President of Rodrigo Duterte has come to power in June 2016. When he started his presidency, Duterte stated that he would pursue the "Independent Foreign Policy" which aims to maintain the good relations among the countries (CSIS, 2018). Independent foreign policy express as the base of the cultivating a diversified range of relationships, based on the Philippines' national interests which are made to maximize the Philippines' autonomy, prosperity, and security (Parameswaran, 2019). In this case, Duterte's foreign policy aims to revive the equi balancing policy on China. Equi balancing is a small power policy of fostering the activities and the relations between two competing major powers to the level where they can shape or influence their policy and self-protection from the external influences(Castro R. C., 2014).

Conceptually, the equi balancing policy refers to the Southeast Asian policy where the policy of a state is not used to balance its relationship with the great power but to involve them through the multilateral institutions such as ASEAN (Renato Cruz De Castro, 2016).The use of equi balancing was aimed to adjust China's presence as the new rising power in the region. There are two reasons that triggered the states are implementing the equi 
balancing policy; First, the equi balancing is a "soft balancing" policy that prevent use of military. Second, it allows small states to preserve good economic relations especially in trade with major powers, for example China. The application of the Philippines equi balancing policy aims to achieve two systematic factors which are; to balance the Philippines security relations with the US and to manage closer relations with China to solve the South China Sea dispute (Castro R. C., 2016).

Having said that, this article explicates the shift and continuity of Philippines foreign policy on the South China Sea issue and focuses the discussion is on the Philippines and China relations toward the South China Sea. It is divided into several sections. The first section looks at the national interests of Philippines to South China Sea. The second section discusses about Philippines Foreign Policy in the South China Sea. The next part analyses the shift and continuity of Philippines foreign policy under Benigno Aquino III and Rodrigo Duterte.

\section{Theoretical Framework}

\section{Foreign Policy}

Joseph Frankel argued that foreign policy can be defined as series of actions and decisions that involves to some appreciable stage of relations among states. The foreign policy usually involves the set of action which made inside the state border and intended to the existing force outside the country's border. It consists of strategy and implementations of the ideas which set the behavior of states while interrelate with other states to obtain the national interests (Frankel J, 1968).

While Hill defined that "the foreign policy is the hinge of domestic and international politics" which means the foreign policy of a country is used as a intersection point from domestic and international politics which will contribute on how a state will use its foreign policy (Hill.C, 2003). Another views came from George Modelski which defined the foreign policy as "the 
system of activities that developed by the community to change the other country's behavior and to adjust their own activities to the international environment" (Laura N, 2008). The foreign policy explained "the ways states attempt to change and succeed in changing the other states behavior". Modelski also highlighted the policy aspect that changed the current state behavior as the main purpose of the foreign policy. Moreover, the foreign policy isn't only aimed to change, but also the continuity of the state behavior at different times (Laura N, 2008).

\section{National Interests}

According to Kenneth Waltz, national interests can be claimed as a structure products of the international system rather than related to the management of the political leaders where the national interests seem to use as a signal to command the state leader about where and when to move(Burchill, 2005). The definition of national interests can be seen through the anarchy condition from the international system. Generally, Neo-Realist argues the world is anarchical and the states will always feel insecure because of there are a lot of inevitable competition and there will be a lot of conflicts among the states in the international system (Burchill, 2005).

Because of those insecure situations, the concept of national security is quite significant for the states to define it as a territorial integrity and state survival (Burchill, 2005). National interests in the strategic term is defined as the states task fulfillment to protect their states by deploying the military power or to have a cooperative defense rule with a stronger strategic power (Burchill, 2005). The national interests is influenced by the anarchy conditions of the international system which create a conflict among states that will be impacted to state stability, survival, and security of the states. Moreover, the purpose and medium of the national interests are permanent and can not be influenced by the internal government change or the ideology that can be pursued through military power (Burchill, 2005). National 
interests can also be considered as state protection from the external threats from any other countries.

Hans. J Morgenthau explained that the threat to their own country could force themselves to move to achieve and fulfill their needs or interests. Morgenthau also explained how the authority of a country could be so powerful when discussing the national interests. A state policymaker will balance their state conditions to earn their self-help. The economic capabilities of a country will equally the same as military power (Waltz, 1979).

According to Kegley and Wittkopf', national interests of a country can be defined as a simple problem related to the self-defense of a country against the threat that can disturb their life. At the end, the needs to attack other states are used as a self-fulfillment to achieve their needs (Wittkopf, 1993). Besides, Waltz has explained that national interests of a country are to fulfill the security and power aspects as a self-defense protection from the enemy (Anam, 2018). Mearsheimer explains the use of national interests as a method to become a superpower country and to dominate the international system for regional stability (Sorensen, 2013).

To connect with this article, the Philippines' interests in the SCS consists of economy, political, and security interests. The Philippines' political interests are to implements the independent foreign policy and to maintain a good relations to entire states especially with China. The security interests are to preserve the sovereignty and the integrity of the national territory in order to protect the Philippine Exclusive Economic Zone (EEZ ) and territory in Western Spratly Island, and the economy interests in SCS is the natural resources to support the Philippines' economic growths and infrastructure projects (EIA, 2019).

\section{Discussion}

The Philippines' National Interests

Political Interests 
In 2016, when the Philippines' under the Rodrigo Duterte's rise as a president. He implemented the new foreign policy agenda that known as "Independent foreign policy" (Philippines Embassy, 2016). The Independent foreign policy aims to maintain exceptional relations with the major powers and not to take sides with the major power to against other. As it stated in the article II section 7, the Philippines' goals are to implement the Independent foreign policy to all major powers (DFA of the Philippines, 2016). Duterte's independent foreign policy is based on the wisdom of "Development is Peace, and Peace is Development" which means to maintain the Philippines' cooperative relations with other major powers, including China in the South China Sea dispute in order to expand the economic relations of China and the Philippines' (ManilaTimes, 2019). Duterte's independent foreign policy means to make sure the South China Sea dispute won't give any impact to the Philippines' bilateral relations with other ASEAN claimant states and China(Heydarian, 2018).

The Philippines' political interests can be seen on how Philippines' trying to pursue good relations with China over its territorial claim in the South China Sea in order to implement the independent foreign policy to the major powers. For example, as an effort to achieve the goals of the independent foreign policy which is to closer China and the Philippines relation, the Philippines was distancing its relations with its closest ally, the U.S in order to earn China's trust to constructively manage its bilateral relations with China(Castro, Renato Cruz De, 2016).

\section{Economic Interests}

Under Duterte's administration, as it stated in the Republic Act No 7157 which known as "The Philippines Foreign Service Act of 1991" that gives the mandate to the Department of Foreign Affairs to implement the three pillar bases of the Philippines' Foreign Policy, which contained in the third pillar which is to protect the Philippines' economic security (DFA of the Philippines, 2016). The Philippines' is the archipelagic maritime states which make the West Philippines' Sea (Western Spratly Island) are a 
national importance regarding the strategic location and natural resources. West Philippines' Sea is important for the Philippines' economy because West Philippines' Sea is the main source for Philippines' oil and gas which have the potential to fulfill the country's demand in 20 years to come, not only that it also hosting the wide array of seabed minerals. The Philippines' oil and gas production are clustered around the offshore of the northwest Palawan and Reed bank in the West Philippines' Sea.

Both areas are having the greatest potential for the country which dependent on the oil imports in this area(Diplomat, 2013).The Philippines' goals are to keep developing the offshore hydrocarbons exploration and the development capabilities. Not only that the Philippines' also used that in order to attract the local and foreign investor in exploiting the natural resources (Diplomat, 2013). Therefore, as the South China Sea is the world most important energy trade route, specifically in the disputed Spratly Island which surround by the fishing ground, not only that Spratly Island is having the potential for oil and gas deposit (EIA, 2019). Hence, there's no doubt that the economic aspect of the SCS has triggered neighborhood claimant states are growing their interests in that region including the Philippines'. The claim of the Philippines over western Spratly Island consists of Scarborough Shoal, Mischief reef, and land is located inside the Philippine's EEZ (Bawaskar, 2019).

As the South China Sea is the hub of oil resources, the Philippines' is having economic interests in the oil production of the SCS and it has made the Philippines' brought the external allies to dig jointly over the oil resources in that region. For examples, the Philippines' made the agreement with India for the oil production and projection over the oil resources of the SCS (Bawaskar, 2019). Second, South China Sea is important for Philippines' economic growth, because the SCS is the source of the Philippines' fishery industry. The totals Gross National Product (GNP) was around $5 \%$ that accounts from the fishery industry and there are totals 
around 5 million of Philippines' citizen are fisherman(Bawaskar, 2019). Therefore, the Philippines' is one the biggest fishing industry in the world.

The Philippines' also employed around 1.5 million traditional fisherman and accounts around $2.7 \%$ of the national Gross Domestic Product (GDP) with total fishing production around three fourth is coming from the SCS (Adam Greer, 2016).As the SCS is the important area to expand the Philippines' economic aspects, in order to fulfill the Philippines' dependency for Philippines' oil and gas in order to fulfill the Philippines fuel demand in the 20 years to come. In order to maintain and protecting the Philippines' economic interests in the SCS, the Philippines' is pursuing the Joint exploration with China regarding the natural resources in the West Philippines' Sea or known as West Spratly Island(Reuters, 2018).

Besides of natural resources, the Philippines' economic interests are also focuses on the development of national infrastructures. Under Duterte administration, he emphasized more on the Philippines infrastructure and he believed that one of the problems of the Philippines was caused by the poor infrastructure.He started to prioritize the development of the Philippines' infrastructure as it will create the employment and could reduce the inequality and poverty (Renato Cruz De Castro, 2018). In order to achieve the economic interests, under Duterte administration, he has pursued the bilateral relations with China in order to earn China support on Philippine economic aspects such as on the modern infrastructure and big project investment on the Philippine peripheries in Mindanao (AMTI, 2016)

\section{Security Interests}

The Philippines' foreign policy has always prioritized the national security of the country, as it has stated in the "Republic Act No 7157" or known as "The Philippines' Foreign Service Act of 1991 " that gives the mandate to the Department of Foreign Affairs to implements the three pillar base of the Philippines' foreign policy, which stated in the first point of the pillar on the "Preservation and enhancement of national security"(DFA of the 
Philippines, 2016). Hence, that's important for Philippines' to protect its national territory and national security from the traditional and nontraditional security threats such as the SCS territorial dispute (DFA of the Philippines, 2016).Linked to the economic interests, as SCS region holds the important Sea Lanes of Communications, energy trade route and also contains a lot of natural resources that important to expand the Philippines' economic aspects. Hence, the SCS is the main area for the Philippine armed force to protect the Philippine EEZ claim on western Spratly Island especially from China aggressiveness over the SCS region.

As an effort protect Philippines' claim in the western Spratly Island, the Philippines' brought the territorial dispute with China to the Permanent Court Arbitration regarding China's aggressive claim in the SCS and the Philippines' is finding a decision regarding on "the source of the Parties' rights and obligations in the South China Sea and the effect of the United Nations Convention on the Law of the Sea (UNCLOS) on China's claim in the SCS" (PCA, 2016). In addition, the security interest of the Philippines' is to protect Philippines' EEZ and Philippine's territorial claim in the Western Spratly Island by sending the armed force to occupy Philippines' claimed island from China in the SCS region (DW, 2017).

For instance, in 2017, President Rodrigo Duterte sent and deployed the troops to occupy and fortify all of the Philippine's claimed island over South China Sea specifically in the Spratly Island which aims to increase the assertiveness of the country's claim. On June 12, Duterte also stated that he will visit the Philippines' claimed area in order to mark in the 119 years of Philippines' independent day(DW, 2017).In order to protect the Philippines' security interests, Philippines' was also deploying its military forces to fortify and place the Philippines' flag in Spratly Island to prevent China aggressiveness towards Philippines' territorial claim(ForeignPolicy, 2017). 


\section{The Philippines' Foreign Policy Before and After Duterte's Administration Towards China's Assertiveness in the South China Sea Region}

The Philippines' foreign policies have changed significantly from Benigno Aquino to Rodrigo Duterte administration in the case of SCS dispute. During Aquino administration, he was challenging China acts by changing the AFP focal point from domestic security to the territorial defense by tightening bilateral security relations among US-Philippines' in order to earn the military equipment from US. Therefore, under the Duterte's administration, he is unraveling the Aquino's agenda by separating the Philippines- US relations and pursues the constructive bilateral relations with China even though the PCA has announced and awarded to the Philippines' regarding the SCS dispute. The foreign policy of Duterte's expected to resuscitate the equi-balancing policy towards China, different act has taken compare to the previous former president under Aquino(Castro, Renato Cruz De, 2016).

\section{Philippines Foreign Policy under Former President Benigno Aquino Administration}

Figure 1:The Philippines Foreign Policy under the Former President Benigno Aquino III Administration

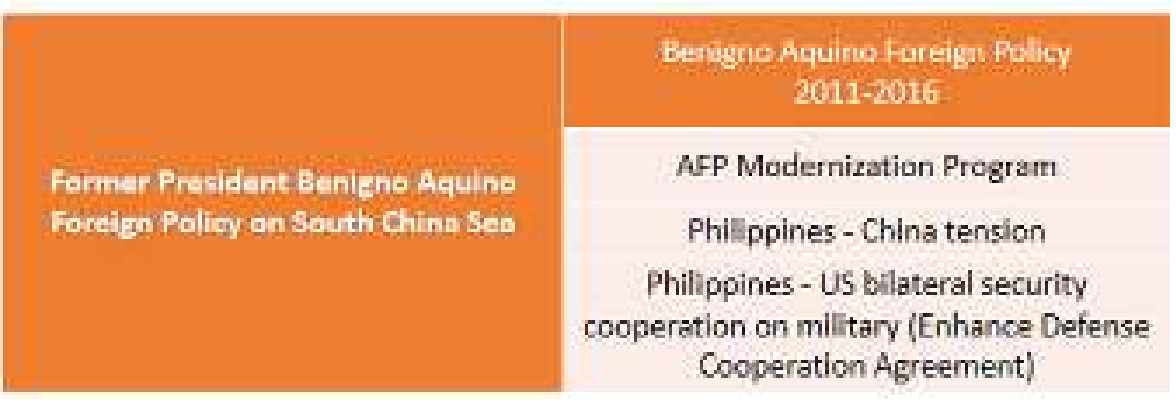

Source: based on the analysis of the authors

After the former President, Benigno Aquino new rise in 2010, Aquino has pursued the foreign policy which known as balancing policy or challenging policy on China in order to promote the security cooperation 
with US(Castro R. C., 2014). In general, under Aquino administration, he has implemented the foreign policy in the security context towards the SCS dispute and it was not included as a part of defense policy because it can be seen there was the US involvement in order to support Philippine AFP modernization and doing closer security cooperation as a matter of his foreign policy(Castro R. C., 2016). Under the former president Benigno Aquino, the Philippines' foreign policy was implemented the bilateral relations in the security aspects with United States in order to support the Philippines' AFP modernization to face China's threat in the western Spratly Island(Castro R. C., 2014). The balancing policy under Aquino means to balance the bilateral relations with the major powers specifically between US and China without only choosing one sides (Javad Heydarian, 2011). Therefore, because of China's aggressive claim on South China Sea, under Aquino's administration has decided to prevent the military aggression of China by making the closer relations to US(Javad Heydarian, 2011). The implementation of the policy can be seen in 2011, when Aquino has stood up regarding the expansive claim of China and China aggressive behavior on SCS.

Aquino has stated about his assertiveness advocacy regarding "the transparency and accountability in the governance and supporting the AFP modernization which aligned to the defense territory" (Castro, Renato Cruz De, 2016). The AFP modernization under Aquino has increase the tensions between Philippine and China. After a year of his presidency, in March 2011, 2 China's patrol boats has destroyed the survey ships which assigned by the Philippine Department of Energy (DOE) to conduct the Reed Bank oil exploration which located near the eastern Spratly Island and around $250 \mathrm{~km}$ located in western Philippine island which is Palawan island. Aquino's administration was shocked with China's movement since the maritime meeting happened in the eastern Spratly and the bordering water. Therefore, couple of days following the incident, the Philippines' government was proposed the protest to the Chinese Embassy in Manila. 
In response, in order to remove the complaint from the Philippine, the China Embassy stated that China has undeniable jurisdiction over the Nansha Island and the bordering territorial waters (Castro, Renato Cruz De, 2016). Continue to the Reed Bank incident and China assertive answer regarding diplomatic question given from the Philippine has forced the former president administration to fasten the expansion of AFP's regarding the regional defense capability. The defense territory of the Philippines aims to build the "Comprehensive border protection program" (Castro, Renato Cruz De, 2016). The boundery patrol capability of Philippine Armed Force (PAF), Philippine Navy(PN), and the Philippine Coast Guard(PCG) that stretching from country territorial waters to the Exclusive Economic Zone(EEZ). The aims require increasing the capability of the AFP, and also the gradual restructuring of the forces for the territorial defense. The 2011 AFP's Strategic Intent stated that the long term goals aim to maintain "the credible posture against the external aggression and other illegal activities which allowing the free navigation to prosper"(Castro, Renato Cruz De, 2016).

As the stipulation to increase the AFP defense capability, the former president governmental was facing the obstacle in the financial ability. Former president Benigno Aquino has admitted that both exigency of armed force modernization was the Philippine Navy (PN) and Philippine Armed Force $(P A F)$.Therefore, Aquino has stated that the armed modernization should be done in developing the reliable defense posture and it isn't used for the war purposes. In 2012, the Philippine is trying to do the negotiation with the US regarding the "Framework Agreement on Enhanced Rotational Presence and Agreement'. These agreements will help to facilitate and to conduct the US troop's deployment and tools for the rotational foundation. The Philippine was relied on the US help in order to earn support in the military modernization and also defense capability through the short term regular visit by the US force which will conduct the joint training with the AFP.

In 2014 April 28, the Philippine and United states has signed the Enhanced Defense Cooperation Agreement (EDCA). The US considered the 
EDCA as the executive agreement which will update and increasing the 1951 Mutual Defense treaty, besides that EDCA has also provided the framework where the Philippine and US both can developing the individual and collective defense capabilities(Castro, Renato Cruz De, 2016). It will also be started with the rotational deployment of US forces in the Philippine which can expand the training opportunity for the Philippine long term military modernization. The EDCA has provided the US military can develop the infrastructure inside the locations and the US will share with the AFP regarding the facilities. Not only had that, in 2013, the Philippine directly encountered China claim in the SCS by proposing the question about its claim towards China in the "Arbitral Tribunal of the United Nation Convention on the Law of the Sea" (UNCLOS). On the statement, the Philippine was asking the tribunal to decide the country legal rights based the UNCLOS for Spratly Island, Mischief Reef, Scarborough Shoal and other land features within the Philippine 200 miles of EEZ(Castro, Renato Cruz De, 2016).

\section{Philippine Foreign Policy under Duterte's New Rise in 2016}

Figure 2: President Rodrigo Duterte's Equi Balancing Policy

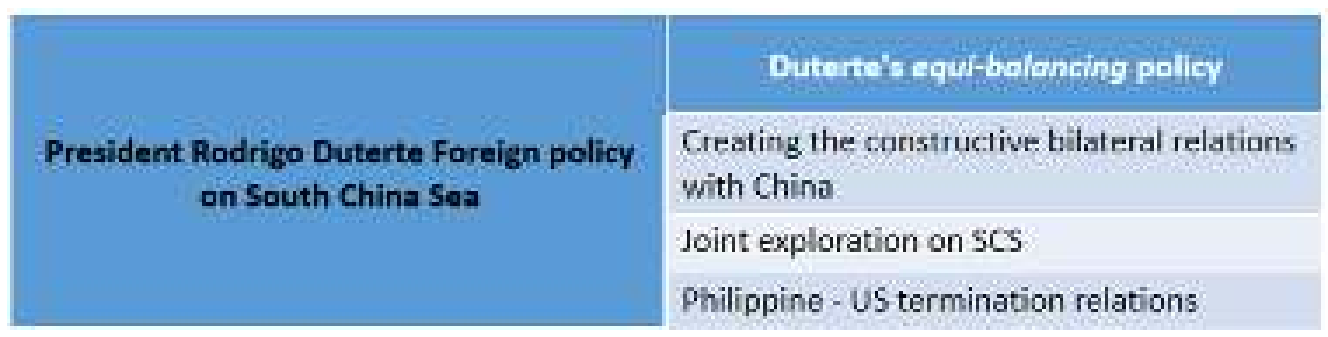

Source; Based on the analysis of the authors

Under Duterte's administration, he has stated that he will pursue the "Independent Foreign Policy" which aims to maintain the good relations among the major nations(Heydarian, 2018). Independent foreign policy express as the base of the cultivating diversified set of relationship which solely based on the Philippines' national interests which made to maximize the Philippine autonomy, prosperity and security(Parameswaran, 2019). In 
his presidency campaign, Duterte stated that he will pursue the good closer relations with China and he won't continue the program of military modernization which started by former president Aquino. His statement indicated that he will not pursue the AFP modernization with the power as much as while under Aquino administration because the AFP modernization was used to challenge China territorial claim on South China Sea.

In this context, Duterte's foreign policy aims to revive the equi balancing policy on China. Equi balancing is a small power policy of fostering the activities and the relation between two competing major powers to the level where they can shape or influenced their policy and self protection from the external influences(Castro R. C., 2014). The using of equi balancing by the states aims to adjust China presence as the new rising power. There are two reasons that triggered the states are implementing the equi balancing policy; first equi balancing is the form of "soft balancing" because of the non military. Second, it allows the small states to preserve the good economic relations especially in trade with China. Therefore, the application of the Philippine equi balancing in the foreign policy aims to achieve two systematic factors which are to balance the Philippines' security relations with the alliance, United States and the Philippines' contentious relations with China regarding the South China Sea dispute(Castro R. C., 2016).

In the first week of Duterte's term, Duterte's has implemented the previous former president Aquino balancing agenda on China. But after his inauguration on June 2016, according to Delfin Lorenzana as the Secretary of National Defense (DND) has make sure to the AFP and Philippines public that under Duterte's administration, he will continue to pursue military modernization, and the Secretary also emphasized that the territorial defense becomes the main priority in order to protect the Philippine territory against the other claimants states. The 15 years of the modernization program of the AFP will carry on as it has been fixed, but under Duterte's regime, there will be some redirection of implication (Castro, Renato Cruz 
De, 2016).The implication of equi balancing policy of Duterte is similar with the previous president, Gloria Macapagal Arroyo's foreign policy where during Arroyo's administration; the Philippine also tried to promote closer relations with China, ignoring the territorial defense and more emphasized and focus on neutralizing the domestic security on terrorism (Castro, Renato Cruz De, 2016). Under Duterte's administration will move to the closer constructive bilateral relations with China and also decreasing the South China Sea tensions if China stops claiming on its sovereignty. Duterte also stated in order to implement the new equi balancing policy of the Philippine in the SCS case, the Philippine will distancing the relations with United States.

Figure 3: The Comparison of Aquino III Foreign policy and Duterte's Foreign Policy
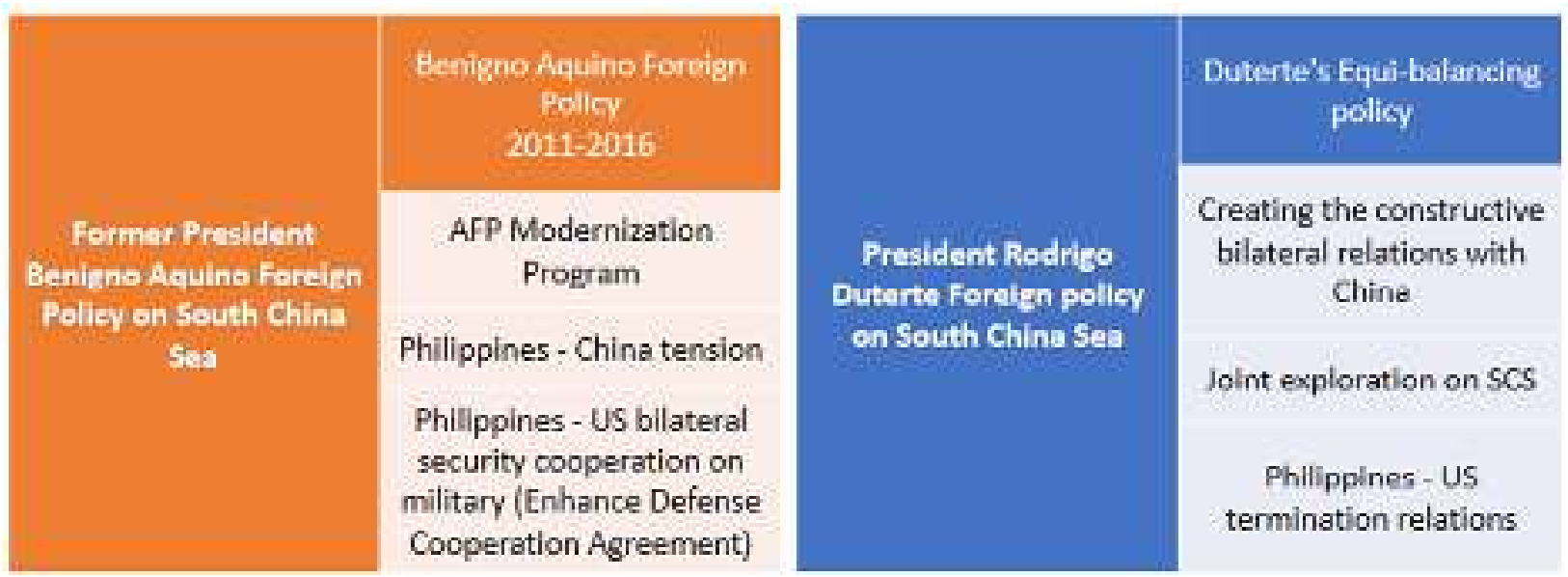

Source: Based on the analysis of the authors

In comparison, the Philippines foreign policy under the former president Benigno Aquino administration and Duterte's administration have changed significantly, where the former President Aquino has implemented the foreign policy in the form of security context which known as balancing policy or challenging policy towards China aggressive claim in the SCS region by promoting the tighten bilateral relations on security with the US, besides challenging China aggressive claim in South China Sea region(Castro R. C., 2016). Therefore, under Duterte administration, Philippines has 
implemented the equi balancing policy which pursues the constructive bilateral relations with China and distancing the Philippines' relations with its allies, United States.

The implementation of the Aquino foreign policy in the security context was by conducting the AFP modernization program and promoting the closer the Philippines bilateral security relations with the US in order to asked the US to facilitate and conducting the American troops deployment and equipment for the Philippines to face China assertive claim in the western Spratly Island, not only making a closer security relations with the United States, but both countries also signing the Enhance Defense Cooperation Agreement (EDCA) where the US were supporting the Philippines' AFP modernization program by giving the opportunities for the training and support for the Philippines' military (Castro, Renato Cruz De, 2016). In the other hand, after Duterte's rise, he has changed the previous balancing policy under Aquino and implementing the Independent foreign policy which aims to conduct the constructive bilateral relations with the major power especially China. As the part of the Independent foreign policy, the Philippines used the Equi balancing policy in balancing the Philippines relation with the two major powers; China, and the US. The implementation of equi balancing policy under Duterte's acts towards the territorial dispute in the SCS was by distancing the Philippines relations with United States and get closer to China by doing bilateral relations and Joint exploration on the South China Sea (AMTI, 2016).

\section{The Philippine Foreign Policy Implementation under Duterte's Administration in the South China Sea Dispute to China}

Independent foreign policy is the new form of foreign policy under Duterte administration which was aimed to maintain the good relations with the major powers(DFA of the Philippines, 2016). The Independent foreign policy express as the base of the cultivating diversified set of relationship which solely based on the Philippine national interests which 
made to maximize the Philippines' autonomy, prosperity and security(Parameswaran, 2019). In this case, the Independent foreign policy made to improve and to intensify the Philippines relations with China in the South China Sea dispute (TheDiplomat, 2017). In order to implement the Independent foreign policy especially in the South China Sea dispute, the Philippine is pursuing the bilateral talks with China regarding the China presence and claim in the West Philippine Sea. Duterte also plans to conduct shared exploration over the natural resources in SCS region (Castro, Renato Cruz De, 2016). In this case, the Philippines were implementing equi balancing policy. Equi balancing is small power policy fostering the activities and the relation between two contended major powers to the level where they can shape or influenced their policy and self protection from the external influences (Castro R. C., 2014). The using of equi balancing aims to balance the Philippines relations with the alliance, United States and the Philippine relations with China regarding the South China Sea dispute (Castro R. C., 2016).

Therefore, in comparison, the independent foreign policy is the basic foundation of the Philippines' foreign policy which aims to pursue and create cooperative bilateral relations between the Philippines' and the entire major powers(DFA of the Philippines, 2016). Because of the independent foreign policy that made to create the good bilateral relations between Philippines and all states. In order to implements the independent foreign policy in the South China Sea dispute. Under Rodrigo Duterte's administration, he has created the Equi balancing policy which specifically made to solve the tension in the South China Sea between China and the Philippines'(Castro R. C., 2016). In conclusion, the independent foreign policy is bigger than equi balancing policy because the Independent foreign policy is the basic foundation of the Philippines' foreign policy and equi balancing policy is the part of the independent foreign policy that use to balance the Philippines' relations with China and US towards the South China Sea dispute. The implementation of the equi balancing agenda can be seen in two ways; first 
is Philippine distancing the relations with US and second is Philippine is trying make closer relations with China in order to pursue constructive bilateral relations in South China Sea (Castro, Renato Cruz De, 2016).

Figure 4: The Philippine Foreign policy implementation under Duterte administration Matrix

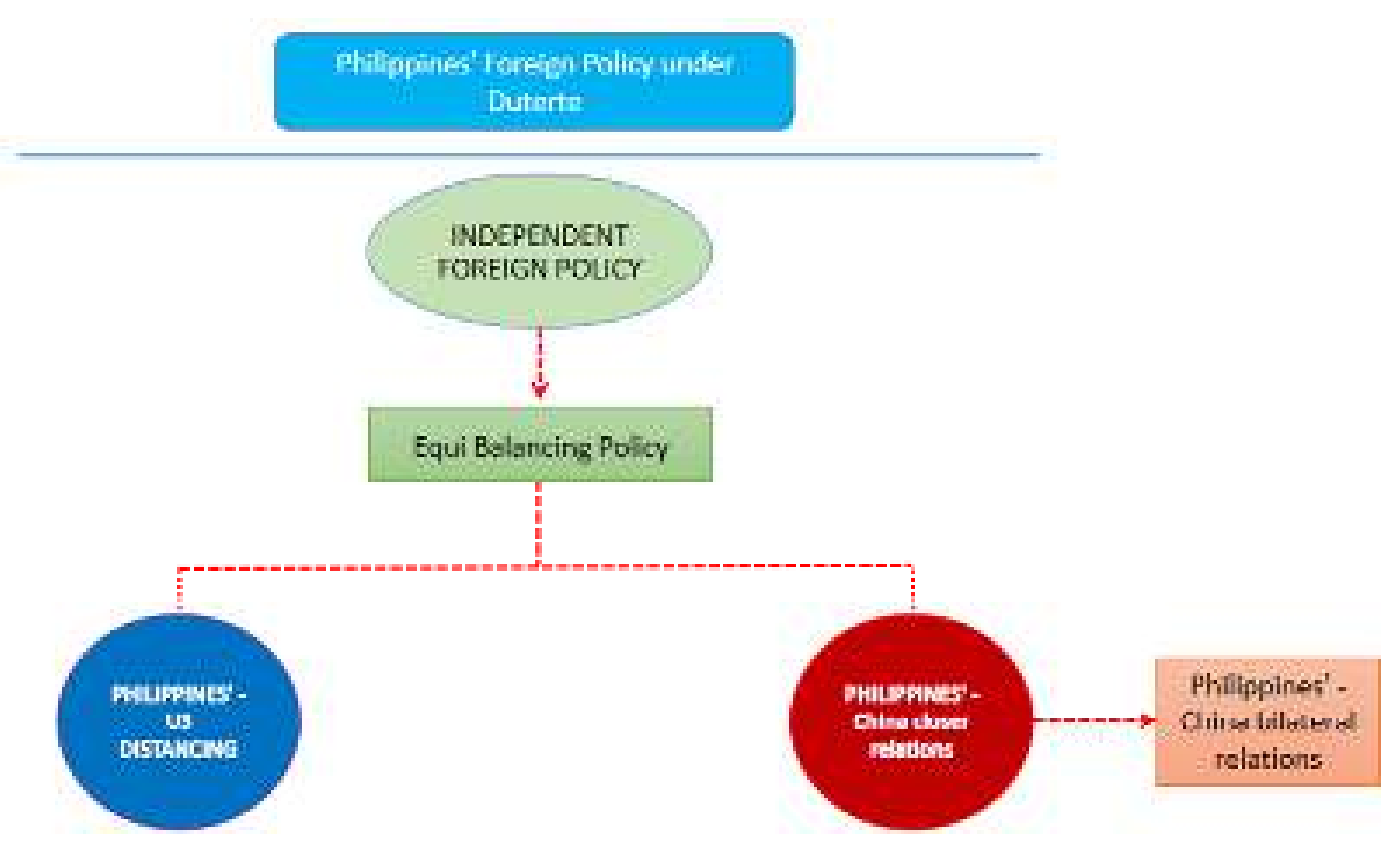

Source: Based on the analysis of the authors.

First, the implementation of equi balancing of Philippine is through distancing Philippines relations with US. In the first place, Philippine is considered to continuing EDCA with the US, because of the limited AFP capabilities in order to secure the Philippine territory in South China Sea towards the threat from China(AMTI, 2016). Therefore, the separation happened was caused by the United States has become critical for its domestic agenda with launching the drug war and that action did by US has taken more than 3000 peoples live. Because of that, Duterte has decided to distance Philippine US relations and at the same time Duterte wanted to 
build the closer relations with China. The implementation of the Philippine distance policy can be seen in the East Asia summit and Two ASEAN summits which held in Laos, Duterte gave a strong speech to the former president Barack Obama and it then led the cancellation of the meeting between the two head of state in the scheduled bilateral meeting. Suddenly in September 2016, Duterte has announced the US special force which were still operating in Minadano to leaving the country with the reason that there will be no peace in the Southern Philippine island if the US force still operating in the region.

Two days after that, Philippine announced the Philippine Navy (PN) to stop join patrol operation with the US Navy in Philippine seas to prevent China to get upset. The announcement of navy separation has clarified by the Perfecto Yasay as the Philippine Foreign Secretary stated that the Philippine armed force would not be capable to fight against China in any battles, hence Duterte has ordered the PN to stop conducting Joint patrol with the US Navy (Castro, Renato Cruz De, 2016). Second, the Philippine implementation of equi-balancing policy to China is through the open bilateral negotiation. After three months of new rise as a president, Duterte has launched the diplomatic offensive to China to earn China's trust by decreasing the SCS tension at the ASEAN summit meeting in Laos to earn China's economic and diplomatic concession. In order to response Philippines' signal to China on this dispute, China has responded positively that China was willing to start the negotiation with Philippine, if the Philippine itself has rejected the PCA award which held in July 12, 2016 (Castro, Renato Cruz De, 2016).

\section{Conclusion}

The foreign policy of the Philippines' has changed significantly due to the shifting of administration from the previous former president Benigno Aquino to Rodrigo Duterte. Under Aquino administration from 2010 to 2016, the Philippines' was implementing the challenging or balancing policy which aims to challenge China's aggressive behavior in claiming the South China 
Sea region. The Philippines was shifting the focus of the Armed Forces of the Philippines' (AFP) from domestic security to territorial defense by conducting the bilateral security relations with the United States and signed the Enhanced Defense Cooperation Agreement (EDCA) on April 28, 2014.

Under Duterte's administration, Philippines implemented the new foreign policy named "Independent Foreign Policy" which aims to maintain good relations among the states. Besides, he was unraveling the former president Aquino balancing agenda by implementing the "equi balancing policy" which also part of the independent foreign policy, which aims to stabilize the Philippines' and the major powers relations in the region; China and the U.S. The equi balancing policy has become the basic foundation of the Philippines' decision to implement a more cooperative maritime diplomacy to China. The implementation of equi balancing was conducted by; first is the termination of the Philippines-U.S joint military exercises in the SCS. Second is Philippines was trying to manage a more cooperative maritime diplomacy with China on the issue of SCS.

\section{Bibliography}

Adam Greer. (2016, July 20). The South China Sea Is Really a Fishery Dispute. Retrieved August 20, 2020, from The Diplomat: https: / thediplomat.com/2016/07/the-south-chinasea-is-really-a-fishery-dispute /

AMTI. (2016, June 30). GEOPOLITICAL CONSTRAINTS ON DUTERTE'S SOUTH CHINA SEA POLICY. Retrieved August 3, 2020, from Asia Maritime Transparency Initiative:

https://amti.csis.org/geopolitical-constraints-dutertes-southchina-sea-policy /

AMTI. (2016, October 19). PRESIDENT DUTERTE MAINTAINS PHILIPPINE-JAPANESE PARTNERSHIP AS HE "PIVOTS” TO CHINA. Retrieved August 3, 2020, from Asian Maritime Transparency Initative: https://amti.csis.org/presidentduterte-maintains-philippine-japanese-partnership-pivotschina/ 
Anam, S. \&. (2018). Kebijakan Belt and Road Initiative (BRI)

Tiongkok pada Masa Pemerintahan Xi Jinping. . Retrieved 2020, from Jurnal Ilmiah Hubungan Internasional.:

https://doi.org/10.26593/jihi.v14i2.284 2.217-236

Bawaskar, R. (2019). The Philippine's Strategy in the South China Sea and the India's Strategic Gestures. 84-89.

Burchill, S. (2005). The national interest in international relations theory. Retrieved March 10, 2020, from https://doi.org/10.1057/9780230005778

Castro, R. C. (2016). 21st Century Philippines Policy Towards an Emergent China: From: Equi Balancing to Strategic Balancing. Asian Politics and Policy(APP) , 306-311.

Castro, R. C. (2014). The Aquino Administration's balancing policy against an Emergent China: its domestic and external dimensions. Pacific Affairs: Volume 87, 6.

Castro, Renato Cruz De. (2016). The Duterte Administration's Foreign Policy: Unravelling the Aquino Administration's Balancing Agenda on an Emergent China. Journal of Current Southeast Asian Affairs, 140.

CSIS. (2018, August 20). Duterte and the Philippines Contested Foreign Policy. Retrieved August 2020, 2020, from Asia Maritime Transparency Initiative:

https://amti.csis.org/duterte-philippines-contested-foreignpolicy/

DCAF. (2020). Defense Policy. Retrieved August 7, 2020, from Geneva Centre for Security Sector Governance : https://securitysectorintegrity.com/defencemanagement/defence-policy/

Departement of Foreign Affairs of the Philippines. (2016, February 10). A PRINCIPLED PHILIPPINE FOREIGN POLICY UNDER THE AQUINO ADMINISTRATION. Retrieved August 7, 2020, from Departement of Foreign Affairs of the Philippines: https://dfa.gov.ph/index.php/speeches/8517-a-principledphilippine-foreign-policy-under-the-aquino-administration

DFA of the Philippines. (2016). Philippine Foreign Policy. Retrieved June 12, 2020, from Embassy of the Philippines: https://romepe.dfa.gov.ph/the-embassy/philippine-foreignpolicy\#: :text=Article $\% 201 \mathrm{I} \% 2 \mathrm{C} \% 20$ Section $\% 207 \% 3 \mathrm{~A} \% 20 \% \mathrm{E} 2$ $\% 80 \% 9$ C,Republic\%20Act $\% 20$ No. 
Diplomat, T. (2013, October 8). The Philippines and the West Philippine Sea. Retrieved August 9, 2020, from https:// thediplomat.com/2013/10/the-philippines-and-thewest-philippine-sea/

DW. (2017, April 6). Duterte to 'raise the Philippine flag' in South China Sea. Retrieved August 2, 2020, from Deutsche Welle: https://www.dw.com/en/duterte-to-raise-the-philippine-flagin-south-china-sea/a-38320961

EIA. (2019, October 15). South China Sea Region. Retrieved June 11, 2020, from US Energy Information Administration : https://www.eia.gov/international/analysis/regions-ofinterest/South_China_Sea

FHI.org. (n.d.). Qualitative Research Methods Overview. Qualitative Research Methods: A Data Collector's Field Guide , 2-3.

ForeignPolicy. (2017, April 6). Philippines To Deploy Troops to Disputed Islands in South China Sea. Retrieved August 8, 2020, from Foreign Policy:

https:/ / foreignpolicy.com/2017/04/06/philippines-duterte-todeploy-troops-disputed-south-china-sea-spratly-islandsgeopolitics-beijing/

Frankel J. (1968). The Making of Foreign Policy. London Oxford University Press, London Oxford University Press.

Heydarian, R. J. (2018, August 20). Duterte and the Philippines Contested Foreign Policy. Retrieved August 2020, 2020, from Asia Maritime Transparency Initiative:

https://amti.csis.org/duterte-philippines-contested-foreignpolicy/

Hill.C. (2003). The Changing Politics of Foreign Policy. New York: Palgrave McMillan.

Javad Heydarian. (2011, October 4). Manila's Balancing Act. Retrieved August 2, 2020, from The Diplomat: https://thediplomat.com/2011/10/manilas-balancing-act/

Laura N. (2008). The New Foreign Policy: Power Seeking in a Globalized Era. Lanham, Md: Rowman \& Littlefield Publishers.

LeMiere, C. (2016). Maritime diplomacy in 21st century. Naval policy and history, 7-14.

ManilaTimes. (2019, July 21). Duterte's independent foreign policy is a pro-Philippine policy. Retrieved August 8, 2020, from 
https://www.manilatimes.net/2019/07/21/opinion/analysis/ dutertes-independent-foreign-policy-is-a-pro-philippinepolicy/587349/

Palmer \& T.Clifton, G. (2006). A Theory of Foreign Policy. Princeton: Princeton University Press.

Parameswaran, P. (2019, October 9). Assessing Philippine Foreign Policy Under Duterte: Current Realities and Future Outlook. Retrieved August 4, 2020, from The Diplomat:

https:/ thediplomat.com/2019/10/assessing-philippineforeign-policy-under-duterte-current-realities-and-futureoutlook/

PCA. (2016, July 12). The South China Sea Arbitration: the Republic of Philippine \& The People's Republic of China. Retrieved July 21, 2020, from Permanent Court Arbitration Press Release: https://docs.pca-cpa.org/2016/07/PH-CN-20160712-PressRelease-No-11-English.pdf

PCG. (2017, February 22). INAUGURAL MEETING OF THE JOINT COAST GUARD COMMITTEE: PHILIPPINE AND CHINA COAST GUARD AGREE TO FURTHER ADVANCE COOPERATION. Retrieved August 3, 2020, from Philippine Coast Guard: http:/ / www.coastguard.gov.ph/index.php/11-news/1484inaugural-meeting-of-the-joint-coast-guard-committeephilippine-and-china-coast-guard-agree-to-further-advancecooperation

Philippines Embassy. (2016). Philippine Foreign Policy. Retrieved June 12, 2020, from Embassy of the Philippines: https://romepe.dfa.gov.ph/the-embassy/philippine-foreignpolicy\#: :text=Article\%20II\%2C\%20Section\%207\%3A\%20\%E2 $\% 80 \% 9$ C, Republic\%20Act $\% 20$ No.

Rabena, A. J. (2018, June 29). Understanding the Philippines' South China Sea Policy. Retrieved August 4, 2020, from Maritime Executive: https://www.maritimeexecutive.com/editorials/understanding-the-philippines-southchina-sea-policy

Renato Cruz De Castro. (2018). How Indo-Pacific Geopolitics Affects Foreign Policy: The Case of the Philippines, 2010-2017. 133155.

Renato Cruz de Castro. (2012). The Aquino administration's 2011 decision to shift Philippines Defense Policy from Internal 
security to Territorial defense: The impact of the South China Sea. The Korean Journal of Defense Analysis , 67-87.

Renato Cruz De Castro. (2016). The Duterte Administration's Foreign Policy: Unravelling the Aquino Administration's Balancing Agenda on an Emergent China. Journal of Current Southeast Asian Affairs , 140.

Reuters. (2018, April 9). Philippines eyes joint exploration deal with China in South China Sea within months. Retrieved August 9, 2020, from https://www.reuters.com/article/us-philippineschina-southchinasea-energ/philippines-eyes-joint-explorationdeal-with-china-in-south-china-sea-within-monthsidUSKBN1HG10G

Rosen, M. E. (2014, August). Philippine Claims in the South China Sea: A Legal Analysis. Retrieved August 8, 2020, from A CNA Occasional Paper : https://www.cna.org/cna_files/pdf/iop2014-u-008435.pdf

Sorensen, J. R. (2013). Pengantar Hubungan Interasional Teori dan Pendekatan. Yogyakarta: Pustaka .

Stake. (2010). Qualitative Research Studying How Things Work. 23.

The Departement of Foreign Affairs of the Philippines. (2019, April 3). PHILIPPINES, CHINA CONVENE THE FOURTH MEETING OF THE BILATERAL CONSULTATION MECHANISM ON THE SOUTH CHINA SEA. Retrieved August 3, 2020, from https://www.dfa.gov.ph/dfa-news/dfa-releasesupdate/21081philippines-china-convene-the-fourth-meeting-of-the-bilateralconsultation-mechanism-on-the-south-china-sea

TheDiplomat. (2017, April 6). US, China, and Duterte's 'Independent Foreign Policy. Retrieved August 8, 2020, from https://thediplomat.com/2017/04/us-china-and-dutertesindependent-foreign-policy/

Waltz, K. N. (1979). Theory of International Politics. McGraw-Hill: New York.

Wittkopf. (1993). World Politics Trend and Transformation (4th ed.). Wittkopf., K. J. C. W. \& E. R. (1993). World Politics Trend and Transformation (4th ed.).. 